\title{
Carbon Sequestration in Soil Cooperated with Organic Composts and Bio-Char during Corn (Zea mays) Cultivation
}

\author{
JoungDu Shin ${ }^{*}$, Sun-Il Lee1, Woo-Kyun Park1, Yong-Su Choi' ${ }^{1}$, Seung-Gil Hong², \\ Sang-Won Park ${ }^{3}$ \\ ${ }^{1}$ Department of Climate Change \& Ecology, National Academy of Agricultural Science, RDA, Wanju, Korea \\ ${ }^{2}$ Department of Organic Agriculture, National Academy of Agricultural Science, RDA, Wanju, Korea \\ ${ }^{3} \mathrm{R} \& \mathrm{D}$ Performance \& Management, Research Policy Bureau, RDA, Jeonju, Korea \\ Email: ${ }^{*}$ jdshin1@korea.kr
}

Received 29 August 2014; revised 30 September 2014; accepted 18 October 2014

Copyright (C) 2014 by authors and Scientific Research Publishing Inc.

This work is licensed under the Creative Commons Attribution International License (CC BY).

http://creativecommons.org/licenses/by/4.0/

(c) (i) Open Access

\begin{abstract}
Background: The objective of this study was to estimate the carbon sequestration in soils cooperated with organic composts and bio-char during corn cultivation. Methods and Results: For the experiment, the soil texture used in this study was clay loam, and application rates of chemical fertilizer and bio-char were $230-107-190 \mathrm{~kg} \cdot \mathrm{ha}^{-1}\left(\mathrm{~N}-\mathrm{P}_{2} \mathrm{O}_{5}-\mathrm{K}_{2} \mathrm{O}\right)$ as recommended amount after soil test and $0.2 \%$ to soil weight. The soil samples were periodically taken at every 15 -day intervals during the experimental periods. The treatments consisted of cow compost, pig compost, swine digestate from aerobic digestion system, and their bio-char cooperation. For estimating soil C sequestration, it is determined by the net balance between carbon inputs and outputs during corn cultivation periods. For the experimental results, it found that applications of aerobic swine digestate, cow compost, and pig compost could sequester $C$ by $38.9 \%, 82.2 \%$ and $19.7 \%$ in soil, respectively, when bio-char from rice hulls was cooperated with soil. For plant responses, application of bio-char in the corn field for carbon sequestration was not occurred the damage of corn growth. Conclusion: When bio-char from rice hulls was cooperated with soil, applications of aerobic swine digestate, cow compost, and pig compost could sequester $C$ by $38.9 \%, 82.2 \%$ and $19.7 \%$ in soil, respectively. Therefore, addition of bio-char with organic composts could have a potential soil C sequestration in agricultural practices.
\end{abstract}

\section{Keywords}

Carbon Sequestration, Total Carbon, Organic Compost, Plant Response

\footnotetext{
${ }^{*}$ Corresponding author.
}

How to cite this paper: Shin, J., Lee, S.-I., Park, W.-K., Choi, Y.-S., Hong, S.-G. and Park, S.-W. (2014) Carbon Sequestration in Soil Cooperated with Organic Composts and Bio-Char during Corn (Zea mays) Cultivation. Journal of Agricultural Chemistry and Environment, 3, 151-155. http://dx.doi.org/10.4236/jacen.2014.34018 


\section{Introduction}

Agriculture and land use change in greenhouse gases, particularly $\mathrm{CO}_{2}$, are estimated to be contributed at $20 \%$ in the total amount of greenhouse gases. There are also reports regarding direct and indirect effects of climate change on crop productivity [1]-[3]. There are reports which indicate that $70 \%-90 \%$ of $\mathrm{CO}_{2}$ emitted to the atmosphere has been attributed to the over consumption of fossil fuel [4] [5]. Burning plant residues, tillage practices, application of chemical fertilizers and change in land use have also been mentioned as the important contributors for evaluating $\mathrm{CO}_{2}$ content in the atmosphere [6].

Bio-char applied to soils has currently generated considerable interest for scientists and policy makers [7], and may be a potential solution for mitigating the greenhouse gas in the agricultural practice. Bio-char is a charcoallike material produced by thermo chemical pyrolysis of biomass. It is being considered as a potentially significant means of storing carbon for long periods to mitigate greenhouse gases [8]. Much of the interest in bio-char comes from studies of Amazonian soils that appear to have been amended with bio-char, but Preta soil in Amazon was naturally generated as a form of bio-char with specific conditions, with significant improvements in soil quality and positive effects on crop production [9]. Bio-char represents a stable form of carbon and thus provides an intriguing potential carbon storage strategy as soil amendment [10].

Bio-char may improve soil physical properties as increase of soil $\mathrm{pH}$ and cation exchange capacity (CEC), and enhancement of nutrient retention. The reduction in $\mathrm{N}_{2} \mathrm{O}$ emissions after bio-char soil amendment was first reported in a greenhouse experiment by Rondon et al. [11]. They found that $\mathrm{N}_{2} \mathrm{O}$ emissions were decreased by up to $50 \%$ for soybean and by up to $80 \%$ for grass growing in a low fertility oxisol from the Colombian savanna. Since then, the interest in bio-char as a $\mathrm{N}_{2} \mathrm{O}$ mitigation strategy for agricultural soils has been continuously increasing, and the number of studies evaluating $\mathrm{N}_{2} \mathrm{O}$ emissions from bio-char treated soils has risen exponentially.

The rate of carbon sequestration is determined by the net balance between carbon inputs and outputs. Carbon inputs and outputs are affected by management and by two biotic processes-production of organic matter in the soil and decomposition of organic matter by soil organism. A desire to find solutions that would enhance soil C sequestration has led to studies of effect of bio-char application on soil organic carbon (SOC) decomposition [12]-[14]. However, both suppression and stimulation of native SOC decomposition by bio-char have been reported by previous studies [14]-[16]. The inconsistent results were probably due to differences in the nature of bio-char and soil, incubation conditions used in different studies [13].

Therefore, this experiment was conducted to estimate the carbon sequestration amount, especially for total carbon in soil cooperated with different composts and their bio-char during corn cultivation periods.

\section{Materials and Methods}

The corn variety used in this experiment was Miback $2 \mathrm{Ho}$, and planting distance was $25 \times 60 \mathrm{~cm}$. Soil texture was clay loam. The experimental design of this study was a randomized split plot design with three replications. The treatments were consisted of cow compost (CC), pig compost (PC), anaerobic digestate (AD), and their biochar cooperation. Fertilizers were applied with $230-107-190 \mathrm{~kg} \cdot \mathrm{ha}^{-1}\left(\mathrm{~N}-\mathrm{P}_{2} \mathrm{O}_{5}-\mathrm{K}_{2} \mathrm{O}\right)$ as whole basal application for $\mathrm{P}_{2} \mathrm{O}_{5}$ and $\mathrm{K}_{2} \mathrm{O}$, and it was especially applied half for basal and half for additional application for nitrogen at 3 day before sowing, based on chemical properties of soil before experiment. CC and PC were applied with 25,000 and $5500 \mathrm{~kg} \cdot \mathrm{ha}^{-1}$ into soil, respectively. AD was applied with 100 ton ha $^{-1}$ in soil that was $16 \%$ of water holding capacity. Chemical properties of soil used were presented in Table 1.

Application rate of bio-char cooperated with soil was $0.2 \%$ of soil weight $\left(1,300,000 \mathrm{~kg} \cdot \mathrm{ha}^{-1}\right)$. Bio-char from rice hull was purchased from local farming cooperative society. Soil samples were periodically collected for 15 days after treatment during corn cultivation periods. The samples were dried and passed through $2 \mathrm{~mm}$ sieve and then stored in refrigerator $\left(4^{\circ} \mathrm{C}\right)$ untilanalyzing the soil chemical properties.

Table 1. Physiochemical properties of soil used in this study.

\begin{tabular}{|c|c|c|c|c|c|c|c|c|}
\hline \multirow{2}{*}{ Soil Texture } & \multirow{2}{*}{$\begin{array}{c}\mathrm{pH} \\
(1: 5)\end{array}$} & \multirow{2}{*}{$\begin{array}{c}E C \\
\left(\mathrm{dS} \cdot \mathrm{m}^{-1}\right)\end{array}$} & \multirow{2}{*}{$\begin{array}{c}\mathrm{OM} \\
\left(\mathrm{g} \cdot \mathrm{kg}^{-1}\right)\end{array}$} & \multirow{2}{*}{$\begin{array}{l}\text { T-C } \\
(\%)\end{array}$} & \multirow{2}{*}{$\begin{array}{l}\text { Av. } \mathrm{P}_{2} \mathrm{O}_{5} \\
\left(\mathrm{mg} \cdot \mathrm{kg}^{-1}\right)\end{array}$} & \multicolumn{3}{|c|}{ CEC $\left(\mathrm{cmol}^{+} \mathrm{kg}^{-1}\right)$} \\
\hline & & & & & & $\mathrm{K}$ & $\mathrm{Ca}$ & $\mathrm{Mg}$ \\
\hline Clay Loam & 6.3 & 0.2 & 15 & 1.03 & 165 & 0.29 & 6.3 & 2.5 \\
\hline
\end{tabular}


Analytical soil chemical properties were total nitrogen (TN), total carbon (TC), total organic carbon (TOC) and total inorganic carbon (TIC) by TOC analyzer (Elementar Vario EL II, Germany). Total carbon combustion temperatures was $950^{\circ} \mathrm{C}$ and $\mathrm{WO}_{3}$ was used as the catalyst. The carbonate was destroyed completely by using 2 $\mathrm{M} \mathrm{HCl}$ until there were no bubbles and fumes, and then samples were dried for another analysis. Thus TOC content was obtained. Total inorganic carbon (TIC) was determined by the difference between TC and TOC. For estimating soil $\mathrm{C}$ sequestration, it is determined by the net balance between carbon inputs and outputs during corn cultivation periods.

\section{Results and Discussions}

For investigating TC contents of input materials, its bio-char was higher at $2 \%$ than CC. Bio-char could be mostly organic carbon as well as their CC and PC due to carbon fractions (data not shown here). However, bio-char could be mostly non-degradable organic carbon on the contrary of its CC and PC because it resists microbial decomposition in the soil for a much longer time than regular biomass [9]. Also, bio-char's carbon bonds don't break down, and remain in soil for centuries [18]. Lowest TC content was observed to be its PC. For nitrogen contents of input materials, TN content of PC was highest at 2.3\%, but lowest one was CC at 1\% (Table 2). Furthermore, TC and TN contents were increased at $20.6 \%$ and 3.7 times, respectively, when compared with original material, rice hull.

Changes of TC contents in the soil applied with different organic composts cooperated with bio-char during corn cultivation periods were described in Figure 1. The effect of input materials for TC in soil were defined as TC contents in the treatments deducted TC contents at initial day of soil sample in the non application plot. Also, effects of biomass for TC were implied TC originated from biomass such as leftovers of tassel, leaf, roots and microorganisms. For soil carbon sequestration, effects of bio-char were TC contents for differences between the compost treatment only and the same compost treated plot cooperated with bio-char. It observed that TC contents were increased with days after sowing, and their peaks were 20 days after sowing (Figure 1). TC contents in treatments cooperated with bio-char at harvesting stages were ranged from $2.09 \%$ to $2.10 \%$, and its CC applied plot was highest at $2.10 \%$.

Estimation of carbon sequestration with TC for organic composts cooperated with bio-char during corn cultivation periods was shown in Table 3. With only application of organic composts, residual amounts of soil TC were ranged from 11,124 to 12,175 $\mathrm{kg} \cdot \mathrm{ha}^{-1}$, and its amount in the PC's plot was highest at 12,175 kg.ha ${ }^{-1}$. With cooperated bio-char, their carbon sequestrations were ranged from 225 to $940 \mathrm{~kg} \cdot \mathrm{ha}^{-1}$, and the highest sequestration was observed to be $82.2 \%$ in CC' plot (Table 3). Lehmann et al. [17] reported that bio-char can sequester up to $50 \%$ of the initial carbon input. However, we found that applications of AD, CC, and PC can sequester C by $38.8 \%, 82.2 \%$ and $19.7 \%$ in the soil, respectively, when cooperated with bio-char from rice hulls into soil. It was observed that recovery rate of total carbon for input bio-char was different with organic composts.

Effects of plant height and fresh biomass weight to application of different organic composts and their cooperated bio-char were shown in Table 4. It was appeared that plant height and fresh weight were not significantly

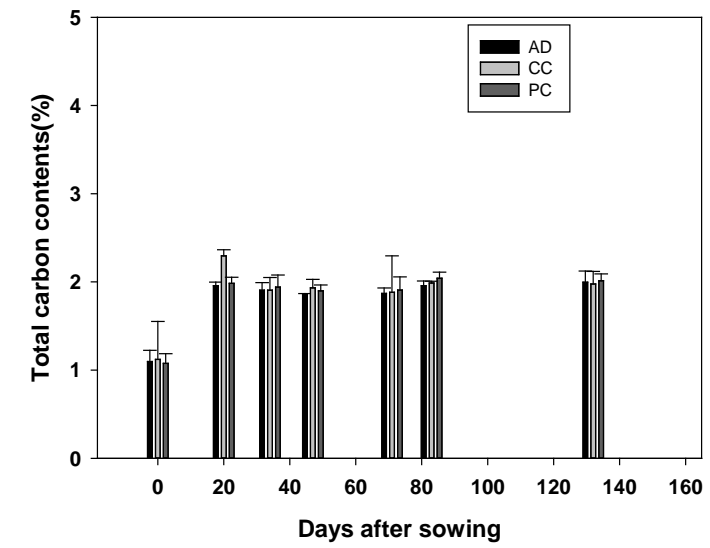

(a)

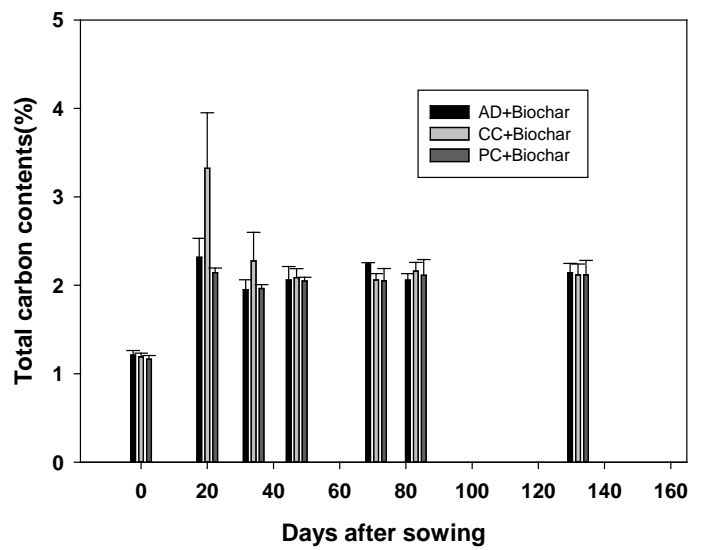

(b)

Figure 1. Changes of total carbon contents in the soil applied with different organic composts and their cooperated with bio-char during corn cultivation periods (AD: aerobic digestates, CC: cow compost, PC: pig compost). 
Table 2. Total carbon and nitrogen contents of input materials.

\begin{tabular}{ccc}
\hline Input materials $^{*}$ & TC (\%) & TN (\%) \\
\hline CC & $41.52 \pm 0.68$ & $0.95 \pm 0.05$ \\
PC & $34.45 \pm 0.42$ & $2.29 \pm 0.06$ \\
Rice hull & $36.47 \pm 0.41$ & $0.37 \pm 0.03$ \\
Bio-char based rice hull & $43.97 \pm 0.86$ & $1.73 \pm 0.02$ \\
\hline
\end{tabular}

${ }^{*}$ CC: cow compost, PC: pig compost.

Table 3. Estimation of carbon sequestration in the soil applied with different composts and their cooperated with bio-char during corn cultivation periods.

\begin{tabular}{ccccc}
\hline Treatments $^{*}$ & Compost only (A) & With bio-char (B) & C-sequestration (B-A) & Recovery rates $^{* *}$ \\
\hline & & - & & $(\%)$ \\
AD & 11,685 & 12,129 & 444 & 38.8 \\
CC & 11,124 & 12,064 & 940 & 82.2 \\
PC & 12,175 & 12,400 & 225 & 19.7 \\
\hline
\end{tabular}

${ }^{*} \mathrm{AD}$ : aerobic digestates, CC: cow compost, PC: pig compost. ${ }^{* *}$ Bio-char input: $2600 \mathrm{~kg} \cdot \mathrm{ha}^{-1}$ (TC: $44 \%$ ).

Table 4. Plant responses to applications of different organic composts and their cooperated with bio-char.

\begin{tabular}{|c|c|c|c|}
\hline \multicolumn{2}{|c|}{ Treatments* } & \multirow{2}{*}{$\begin{array}{c}\text { Plant height }(\mathrm{cm}) \\
124.0 \pm 7.83\end{array}$} & \multirow{2}{*}{$\begin{array}{c}\text { Fresh biomass weight }\left(\mathrm{kg} \cdot \mathrm{ha}^{-1}\right) \\
\qquad 10,520 \pm 199\end{array}$} \\
\hline & CC & & \\
\hline \multirow[t]{3}{*}{ Compost only } & PC & $134.1 \pm 7.40$ & $15,570 \pm 212$ \\
\hline & $\mathrm{AD}$ & $112.3 \pm 5.40$ & $10,400 \pm 188$ \\
\hline & CC & $122.8 \pm 5.71$ & $11,270 \pm 191$ \\
\hline \multirow[t]{2}{*}{ With bio-char } & PC & $117.3 \pm 6.36$ & $10,150 \pm 669$ \\
\hline & $\mathrm{AD}$ & $113.8 \pm 12.01$ & $10,630 \pm 477$ \\
\hline
\end{tabular}

${ }^{*} \mathrm{AD}$ : aerobic digestates, CC: cow compost, PC: pig compost.

different between application plots of organic composts and plots cooperated with bio-char. It was determined that application of bio-char in the corn field for carbon sequestration was significantly not occurred the damage of corn growth and enhanced the fresh biomass weight of corn except PC treatment. However, it was indicated that declines in plant growth in some experiments with bio-char has been attributed a decline in available ammonium [19].

\section{Summary}

For the experimental results, it observed that applications of AD, CC, and PC can sequester C by $38.9 \%, 82.2 \%$ and $19.7 \%$ in soil, respectively, when cooperated with bio-char from rice hulls into soil. For plant responses, application of bio-char in the corn field for carbon sequestration did not show the damage of corn growth and enhanced the fresh biomass weight of corn except PC treatment. Therefore, addition of bio-char with organic composts could have a potential soil C sequestration in agricultural practices. For the future study, application of pellet form of bio-char with organic compost in agricultural land need to be more elucidated soil $\mathrm{C}$ sequestration in practice with labor save and reduction of non point contaminant.

\section{Acknowledgements}

This study was carried with the support of "Research Program for Agricultural science \& Technology Development (Project No. PJ 00858402)”, National Academy of Agricultural Science, Rural Development Administration, Republic of Korea. 


\section{References}

[1] Koocheki, A. and Nassiri Mahallati, M. (2008) Impact of Climate Change and $\mathrm{CO}_{2}$ Concentration on Wheat Yield in Iran and Adaptation Strategies. Iranian Journal of Field Crops Research, 6, 139-153.

[2] Koocheki, A., Nassiri, M., Kamali, G.A. and Shahandeh, H. (2006) Potential Impact of Climate Change on Agro-Meteorological Indicators in Iran. Arid Land Research and Management, 20, 245-259. http://dx.doi.org/10.1080/15324980600705768

[3] Koocheki, A., Nassiri, M., Soltani, A., Sharifi, H. and Ghorbani, R. (2006) Effects of Climate Change on Growth Criteria and Yield of Sunflower and Chickpea Crops in Iran. Climate Research, 30, 247-253. http://dx.doi.org/10.3354/cr030247

[4] IPCC (1996) Intergovernmental Panel on Climate Change. Climate Change 1995: The Science of Climate Change, Cambridge University Press, Cambridge.

[5] IPCC (1999) Intergovernmental Panel on Climate Change, Data Distribution Center. CD-ROM Version 1.0. Providing Climate Change and Related Scenarios for Impact Assessments, Climatic Research Unit, University of East Anglia, Norwich.

[6] Lal, L. (2002) Soil Carbon Dynamics in Cropland and Rangeland. Environmental Pollution, 116, 353-362. http://dx.doi.org/10.1016/S0269-7491(01)00211-1

[7] Atkinson, C.J., Fitzgerald, J.D. and Hipps, N.A. (2010) Potential Mechanisms for Achieving Agricultural Benefits from Bio-Char Application to Temperate Soils: A Review. Plant and Soil, 337, 1-18. http://dx.doi.org/10.1007/s11104-010-0464-5

[8] Laird, A.D. (2008) The Charcoal Vision: A Win-Win-Win Scenario for Simultaneously Producing Bioenergy, Permanently Sequestering Carbon, while Improving Soil and Water Quality. Agronomy Journal, 100, 178-184. http://dx.doi.org/10.2134/agrojnl2007.0161

[9] Lehmann, J., Kern, D.C., Glaser, B. and Woods, W.I., Eds. (2004) Management. Kluwer Academic Publishers, New York.

[10] Mathews, J.A. (2008) Carbon-Negative Biofuels. Energy Policy, 36, 940-945. http://dx.doi.org/10.1016/j.enpol.2007.11.029

[11] Rondon, M., Ramirez, J.A. and Lehmann, J. (2005) Greenhouse Gas Emissions Decrease with Charcoal Additions to Tropical Soils. http://soilcarboncenter.k-state.edu/conference/USDA\%20Abstracts\%20html/Abstract\%20Rondon.htm

[12] Wardle, D.A., Nilsion, M.C. and Zackrisson, O. (2008) Fire-Derived Charcoal Cause Loss of Forest Humus. Science, 320, 629.

[13] Jones, D.L., Murphy, D.V., Khalid, M., Ahmad, W., Edwards-Jones, G. and DeLuca, T.H. (2011) Short-Term Biochar Induced Increase in Soil $\mathrm{CO}_{2}$ Release Is both Biotically and Abiotically Mediated. Soil Biology and Biochemistry, 43, 1723-1731. http://dx.doi.org/10.1016/j.soilbio.2011.04.018

[14] Luo, Y., Durenkamp, M., De Nobili, M., Lin, Q. and Brookes, P.C. (2011) Short Term Soil Priming Effects and the Mineralization of Biochar Following Its Incorporation to Soils of Different pH. Soil Biology and Biochemistry, 43, 2304-2314. http://dx.doi.org/10.1016/j.soilbio.2011.07.020

[15] Liang, B.Q., Lehmann, J., Sohi, S.P., Thies, J.E., O’Neill, B., Trujillo, L., Gaunt, J., Solomon, D., Grossman, J., Neves, E.G. and Luizao, F.J. (2010) Black Carbon Effects the Cycling of Non-Black Carbon in Soil. Organic Geochemistry, 41, 206-213. http://dx.doi.org/10.1016/j.orggeochem.2009.09.007

[16] Cross, A. and Sohi, S.P. (2011) The Priming Potential of Biochar Products in Relation to Labile Carbon Contents and Soil Organic Matter Status. Soil Biology and Biochemistry, 43, 2127-2134. http://dx.doi.org/10.1016/j.soilbio.2011.06.016

[17] Lehmann, J. (2009) Biological Carbon Sequestration Must and Can Be a Win-Win Approach. Climatic Change, 97, 459-463. http://dx.doi.org/10.1007/s10584-009-9695-y

[18] Kuzyakov, Y., Subbotina, I., Chen, H., Bogomolova, I. and Xu, X.L. (2009) Black Carbon Decomposition and Incorporation into Soil Microbial Biomass Estimated ${ }^{14} \mathrm{C}$ Labeling. Soil Biology and Biochemistry, 41, 210-219. http://dx.doi.org/10.1016/j.soilbio.2008.10.016

[19] Deenik, J.L., McClellan, T., Uehara, M., Antal, M.J. and Campbell, S. (2010) Charcoal Volatile Matter Content Influences Plant Growth and Soil Nitrogen Transformations. Soil Science Society of America Journal, 74, 1259-1270. http://dx.doi.org/10.2136/sssaj2009.0115 
Scientific Research Publishing (SCIRP) is one of the largest Open Access journal publishers. It is currently publishing more than 200 open access, online, peer-reviewed journals covering a wide range of academic disciplines. SCIRP serves the worldwide academic communities and contributes to the progress and application of science with its publication.

Other selected journals from SCIRP are listed as below. Submit your manuscript to us via either submit@scirp.org or Online Submission Portal.
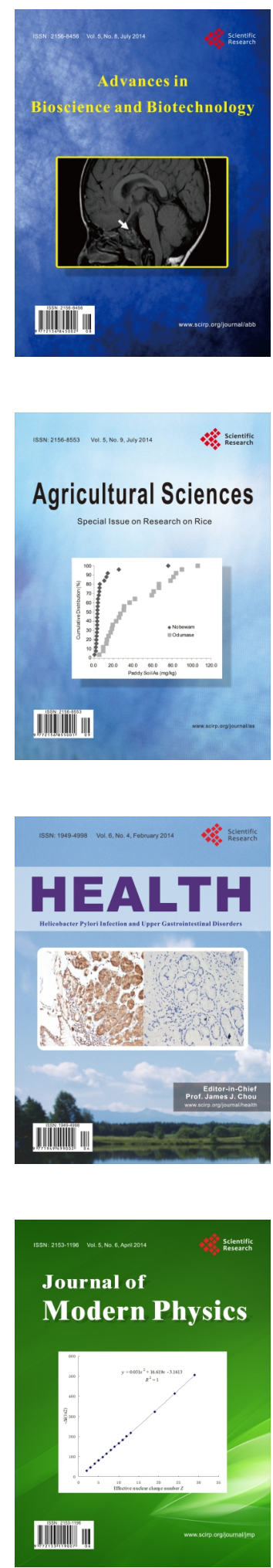
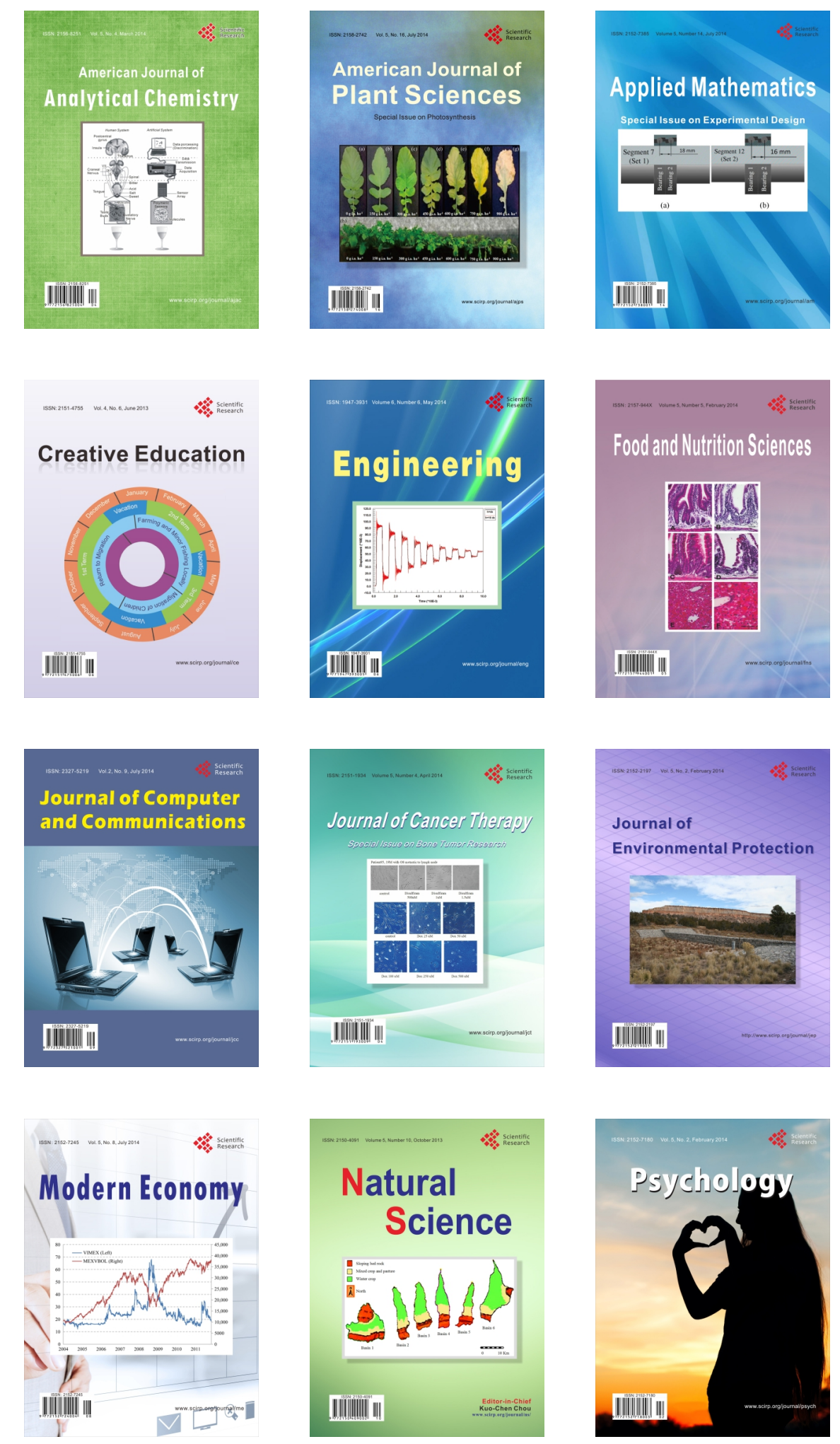